\title{
Identification of anatomically non-distinct annual rings in tropical trees using stable isotopes
}

\author{
Thijs L. Pons • Gerhard Helle
}

Received: 30 October 2009/Revised: 19 November 2010/Accepted: 26 November 2010/Published online: 14 December 2010

(C) The Author(s) 2010. This article is published with open access at Springerlink.com

\begin{abstract}
Annual rings are generally not anatomically distinct in trees growing in the humid tropics. The possibility to use radial variation in stable isotopes $\left(\delta^{18} \mathrm{O}\right.$ and $\left.\delta^{13} \mathrm{C}\right)$ for the identification of annual rings in these trees was investigated in two species growing in the tropical rainforest of Central Guyana, Carapa guianensis and Goupia glabra. The climate is characterised by an annual precipitation of $2,700 \mathrm{~mm}$ that is distributed over two rainy and two dry seasons. Cores were taken from trees of measured diameter increment rates. High-resolution tangential sections in radial direction were dissected from these cores and isotopic ratios were measured on whole wood. Variation in $\delta^{13} \mathrm{C}$ was about $1 \%$ at an annual scale, whereas $\delta^{18} \mathrm{O}$ showed two to four times larger annual excursions. The minima in $\delta^{18} \mathrm{O}$ were selected as primary indicators of annual boundaries at the main wet season when also $\delta^{18} \mathrm{O}$ of precipitation water has its minimum. The minima in $\delta^{13} \mathrm{C}$ coincided often with these. The simultaneous occurrence is consistent with increased discrimination against ${ }^{13} \mathrm{C}$ at high water availability. They were used as secondary criteria. Annual rings could thus be identified with reasonable certainty in both species from radial variation in isotopic ratios as verified
\end{abstract}

Communicated by A. Braeuning.

Contribution to the special issue "Tropical Dendroecology".

T. L. Pons $(\bowtie)$

Department of Plant Ecophysiology,

Institute of Environmental Biology,

Utrecht University, Padualaan 8, 3584 CH Utrecht,

The Netherlands

e-mail: T.L.Pons@uu.nl

G. Helle

German Centre for Geosciences, Section 5.2,

Helmholtz-Centre Potsdam, 14473 Potsdam, Germany with measured diameter increment rates. The short sequence covered in the analysis did not show clear correlation with the available precipitation data for the area. The method supplemented with other dating methods may prove to be practically useful for identifying annual rings and applying classical dendrochronology when more cost effective automatic sampling devices become available.

Keywords Tree ring - Stable carbon isotope $\cdot$ Stable oxygen isotope - Tropical rainforest - Carapa guianensis . Goupia glabra

\section{Introduction}

Tree rings have been used for a long time in areas outside the tropics as a powerful tool for the retrospective analysis of tree growth and its response to environmental factors. Stable carbon and oxygen isotope composition of the wood or wood constituents in these rings are increasingly included in the analyses for inferring environmental conditions and tree physiological responses (McCarroll and Loader 2004; Sternberg 2009). However, the absence of distinct annual rings in many tropical trees has so far prohibited the general use of these tools in the tropics. Although the existence of annual rings in some species of tropical trees has been known for a long time (Jacoby 1989), the more general use of ring chronologies in the tropics is of more recent date. An increasing number of reports show that annual boundaries can indeed be formed in the wood of tropical trees when a dormancy period is induced by a dry season (Worbes 2002; Heinrich et al. 2008). Seasonally deciduous species are most likely to form distinct rings, but evergreens may also do so (Brienen and Zuidema 2005). Environmental stresses other than drought have also been 
shown to induce an annual pattern in wood structure, such as flooding and a seasonally high salinity (Schöngart et al. 2002; Verheyden et al. 2004a). The recognition of annual rings has opened opportunities for a classical dendrological approach as used for temperate trees (e.g. Brienen and Zuidema 2006). The identification of distinct rings has furthermore opened the possibility to use stable isotopes for deriving past environmental responses in these trees (Poussart et al. 2004; Verheyden et al. 2004b; Hietz et al. 2005; Cullen et al. 2008; Brienen et al. 2010). However, a large number of evergreen tropical trees do not form distinct annual tree rings, particularly so in the humid tropics that lack a pronounced dry season (Jacoby 1989). This is a serious shortcoming since it precludes a dendrological approach and the use of stable isotopes for retrospectively analyzing the effect of environmental factors on tree growth and for palaeoclimatology.

The use of stable carbon isotopes in plant material in general and tree rings in particular has become wide spread when a good model became available predicting environmental effects on isotopic ratios $\left(\delta^{13} \mathrm{C}\right.$ ) (Farquhar et al. 1982, 1989). Discrimination against ${ }^{13} \mathrm{C}$ during photosynthetic $\mathrm{CO}_{2}$ assimilation in $\mathrm{C}_{3}$ plants decreases with decreasing ratio of intercellular to atmospheric $\mathrm{CO}_{2}$ concentration $\left(C_{\mathrm{i}} / C_{\mathrm{a}}\right)$. This denotes increasing stomatal limitation of photosynthesis caused by either a decrease in stomatal conductance $\left(g_{\mathrm{s}}\right)$ and/or an increase in photosynthetic rate $(A)$. The resulting increased intrinsic water use efficiency $\left(A / g_{\mathrm{s}}\right)$ is thus associated with isotopically enriched plant carbon (increased $\delta^{13} \mathrm{C}$ ). Drought typically increases stomatal limitation of photosynthesis, whereas shading reduces it, thus showing corresponding excursions in $\delta^{13} \mathrm{C}$ (Francey and Farquhar 1982). In tree rings, the straightforward interpretation of these model predictions is complicated by post assimilation fractionation processes. In particular, wood growth from stored reserves rather than from current assimilates complicates matters. This results in carry-over effects from the previous growth season to early wood formation in the next in addition to fractionation associated with starch metabolism (Helle and Schleser 2004; Kagawa et al. 2006; Gessler et al. 2009).

The mechanistic understanding of variation in $\delta^{18} \mathrm{O}$ in plant material became available more recently (Roden et al. 2000; Barbour 2007; Sternberg 2009). The oxygen in water exchanges with that in $\mathrm{CO}_{2}$ before its assimilation and in carbonyl groups of assimilates. Assimilates, thus carry the isotopic signal of leaf water, albeit at about $27 \%$ enrichment. The $\delta^{18} \mathrm{O}$ of leaf water is the result of the $\delta^{18} \mathrm{O}$ of water taken up by the tree (source water) and subsequent enrichment during transpiration and exchange with atmospheric water vapor in the leaf. Further downstream with synthesis of wood constituents in the stem, another exchange step occurs. The isotopic composition of source water is thus dominant in stem wood, since source water forms the basis of leaf water and is partially exchanged during the synthesis of wood constituents from sucrose.

Seasonal variation in precipitation also exists in humid tropical climates. Dry seasons could thus be reflected in an increased $\delta^{13} \mathrm{C}$ of wood then synthesized from current assimilates. Wet seasons in the tropics are characterized by ${ }^{18} \mathrm{O}$ depleted precipitation water (Araguas-Araguas et al. $2000)$, thus leading to a reduced $\delta^{18} \mathrm{O}$ of source water. A parallel seasonality is thus expected for $\delta^{13} \mathrm{C}$ and $\delta^{18} \mathrm{O}$. When sampled at a sufficiently high radial resolution relative to the level of growth assumed for a certain site, the stable isotope composition of the wood is thus potentially suitable for the identification of annual tree rings when not anatomically distinct. Another prerequisite for a successful application of this approach is that seasonal variation in environmental conditions is sufficiently large such that the annual pattern in isotopic composition of the wood is sufficiently pronounced. This would open opportunities for retrospectively analyzing tree growth. Inter-annual variation in precipitation and other environmental conditions is likely to result in between-ring variation in isotopic composition. Past environmental conditions and tree responses could thus be inferred. Variation in $\delta^{13} \mathrm{C}$ in the radial direction in tropical wood samples without rings analyzed by Leavitt and Long (1991) suggested an annual pattern. More recent reports do show the potential of this approach for trees with a non-distinct ring structure from Costa Rica (Evans and Schrag 2004; Anchukaitis et al. 2008) and Thailand (Poussart and Schrag 2005). The tropical climates of these areas are characterized by a single annual wet and a pronounced dry season. In our study area, Central Guyana, two wet and two dry seasons can be distinguished that are not very pronounced (Ter Steege and Persaud 1991) (Fig. 1). The different precipitation pattern compared to the previous studies may induce a different isotopic signal. The majority of the trees in the area do not exhibit a distinct ring pattern (Miller and Détiene 2001).

The principal objective of this study was to further investigate the potential of the use of stable isotopes for the identification of annual rings in trees from the humid tropics that have no anatomically distinct rings. After identification of annual rings, the data are used to investigate the potential for analyzing relationships with environmental variability and tree responses. The study was carried out in the rainforest of Central Guyana with the two species Goupia glabra and Carapa guianesis. Cores were taken from trees of which the diameter increment had been measured. This provided a reference for dating the wood. Measurement of isotopic ratios was done at a sufficiently high resolution to detect intra-annual variation in $\delta^{13} \mathrm{C}$ and $\delta^{18} \mathrm{O}$. 


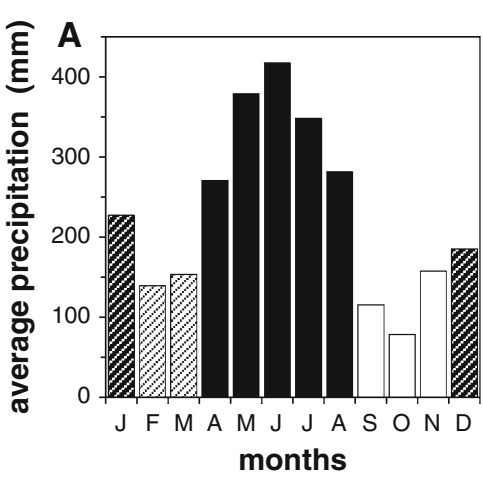

Fig. 1 Precipitation in the Mabura Hill area where the study was carried out. Precipitation was recorded at the sample site and in the vicinity (see text). No data are available for the period 1993-1996.

\section{Materials and methods}

Study site, trees and sampling

The study was carried out in the rainforest in Central Guyana about $40 \mathrm{~km}$ south of the township Mabura Hill in the West Pibiri compartment of a timber harvesting concession $\left(5^{\circ} 02^{\prime} \mathrm{N} ; 58^{\circ} 37^{\prime} \mathrm{W}\right)$. Cores were taken from trees in permanent sample plots where diameter increment rates have been measured since September 1993 (van der Hout 1999). The species Carapa guianensis Aublet and Goupia glabra Aublet were selected because the wood is rather homogeneous and their growth rates were relatively high. The species will further be referred to by their genus names. The average radial increment rate measured on all trees $>20 \mathrm{~cm}$ diameter on three ha was $0.9 \mathrm{~mm}$ per year, whereas the rates for Carapa and Goupia were $1.9 \pm 1.5$ and $1.4 \pm 1.1$, respectively. Hence, the increment rates of the sample trees were generally above average (Table 1). Goupia is a common species of secondary forests and Carapa is most common in marsh forests and along rivers and creeks. Both species are also regularly found in the mixed primary forests on the well-drained brown loamy sands (Ferralsols) of the research site. They are evergreen in the area, although seasonal periodicity in leaf fall and leaf growth may exist.

Cores were sampled from opposite sides (north and south) of the stems of two trees of each species growing in an undisturbed experimental plot at May 2, 2002. The cores were taken at breast height with a power driven $10 \mathrm{~mm}$ core drill until a depth of about $4 \mathrm{~cm}$, which covered at least the radial increment over the measurement period. The cores were air dried and rectangular pieces were trimmed to approximately $5 \times 5 \mathrm{~mm}$. The upper transverse surface was planed and photographed. One core of each species was tangentially cut in slices of $200 \mu \mathrm{m}$ thickness using a device with a cutting knife and a screw
The annual mean was 2,680 $\mathrm{mm}$. a Monthly averages for these data. b Deviations from the seasonal mean during the observation period. The four seasons were distinguished as shown in (a) with legend in (b)

Table 1 List of the four trees that were sampled for the isotopic measurements with stem diameter and growth rate

\begin{tabular}{lll}
\hline & $\begin{array}{l}\text { Stem diameter } \\
(\mathrm{mm})\end{array}$ & $\begin{array}{l}\text { Radial increment } \\
\left(\mathrm{mm} \mathrm{year}^{-1}\right)\end{array}$ \\
\hline Carapa guianensis & & \\
61 & 390 & 1.53 \\
47 & 486 & 2.79 \\
Goupia glabra & & \\
42 & 478 & 2.35 \\
17 & 509 & 2.40
\end{tabular}

The average stem diameter increment at breast height as measured from September 1993 to May 2002 (the moment of sampling). The radial increment rate was calculated for that period and corrected for shrinkage with drying (4.8\% for Carapa and 5.1\% for Goupia)

for advancing the sample. One core per species was cut at a thickness of $60 \mu \mathrm{m}$ using a sledge microtome (Polycut E, Leica microsystems, Bentheim, Germany). The Carapa wood had occasional axial parenchyma bands that were used to align the samples. The rays were used to further align the samples of both species.

Stable isotope analysis

From the $200 \mu \mathrm{m}$ slices, three samples of ca. $0.2 \mathrm{mg}$ were taken for isotopic analysis on whole wood; one for $\delta^{13} \mathrm{C}$ and two for $\delta^{18} \mathrm{O}$ analysis. The samples were cut from one side of the slice. The $60 \mu \mathrm{m}$ slices were subdivided into three parts, also one for the $\delta^{13} \mathrm{C}$ and two for $\delta^{18} \mathrm{O}$ measurements. All slices were analyzed except for the $60 \mu \mathrm{m}$ slices of the Goupia core for which every other slice was measured. The samples were weighed and packed into tin capsules $\left(\delta^{13} \mathrm{C}\right)$ and silver capsules $\left(\delta^{18} \mathrm{O}\right)$. Prior to measurement of $\delta^{18} \mathrm{O}$, the samples were vacuum dried at $60^{\circ} \mathrm{C}$ for 2 days. The samples were combusted $\left(\delta^{13} \mathrm{C}\right)$ or pyrolized $\left(\delta^{18} \mathrm{O}\right)$ at $1,080^{\circ} \mathrm{C}$ in an elemental analyzer (Carlo Erba, Milan, Italy) coupled to an isotope ratio mass 
spectrometer (OPTIMA, Micromass Ltd, Manchester, UK). In the case of $\delta^{18} \mathrm{O}$ measurements, the autosampler was covered with a hood and flushed with Argon gas in order to avoid any contamination from air. The $\delta^{13} \mathrm{C}$ and $\delta^{18} \mathrm{O}$ values are expressed relative to the VPDB and VSMOW standards, respectively. The reproducibility for replicate measurements of tree-ring samples is better than $0.1 \%$ for $\delta^{13} \mathrm{C}$ and $< \pm 0.3 \%$ for $\delta^{18} \mathrm{O}$.

The amount of material of the $60 \mu \mathrm{m}$ slices was insufficient for cellulose extraction. A comparison between wholewood and cellulose was made as follows. Separate series of $200 \mu \mathrm{m}$ slices were cut from parts of the cores beyond the depth where diameter increment rates were known at around $35 \mathrm{~mm}$. These were used for comparison of $\delta^{13} \mathrm{C}$ and $\delta^{18} \mathrm{O}$ in whole-wood and cellulose. The middle part of the slice was used for the measurement on whole-wood. The remainder of the slice was extracted for $\alpha$-cellulose according to common procedures described by Green (1963) and modified after Loader et al. (1997).

\section{Precipitation}

At a nearby station of the Guyana hydrometeorological service (Great Falls; approximately $40 \mathrm{~km}$ north of the sample site), precipitation is measured. However, a continuous record is not available for most of the experimental period. In the framework of a larger research program carried out in the area (Tropenbos-Guyana program), meteorological measurements were done between 1991 and 1993 at a site about $25 \mathrm{~km}$ north of the sample site (Jetten 1994) and between 1996 and 2000 at the sample site (van Dam 2001). The available precipitation records are shown in Fig. 1. The monthly averages presented in Fig. 1 are similar to the averages for the period 1965-1973 measured at the nearby Great Falls meteorological station (Jetten 1994) and provide a good picture of the local precipitation pattern. Precipitation water $\delta^{18} \mathrm{O}$ values were taken from the Water Isotope System for Data Analysis, Visualization, and Electronic Retrieval (WISER) database (http://nds121.iaea.org/wiser/). The nearest station with a similar climate is Cayenne (WMO Station Code 8140501) in French Guyana at about $475 \mathrm{~km}$ to the east for which the data are reproduced in (Fig. 2).

\section{Results and discussion}

Whole-wood with cellulose comparison

The thin $60 \mu \mathrm{m}$ slices were too small for cellulose extraction. The isotopic composition of whole-wood was compared with that of cellulose in larger samples to establish the relationship between the two. They typically

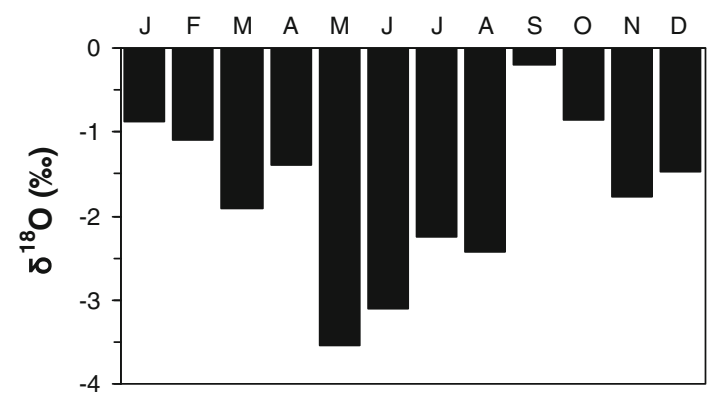

Fig. 2 Monthly averages for $\delta^{18} \mathrm{O}$ in precipitation water for the period 1969-1975, Cayenne, French Guiana [Water Isotope System for Data Analysis, Visualization, and Electronic Retrieval (WISER) database, http://nds121.iaea.org/wiser/]

show similar patterns in $\delta^{13} \mathrm{C}$ with somewhat higher values in cellulose (Helle and Schleser 2004; Loader et al. 2003, Verheyden et al. 2005; Harlow et al. 2006; Eglin et al. 2008). This was confirmed for the series of Carapa and Goupia that were used for this comparison (Fig. 3a, b). The small radial variation of $\delta^{13} \mathrm{C}$ in whole-wood was reflected in the cellulose at $1.1 \%$ and $0.9 \%$ onrichment, respectively, which resulted in high correlation coefficients (0.92 and 0.89 for Carapa and Goupia, respectively).

The $\delta^{18} \mathrm{O}$ values were on average 5.5\% (Carapa) and $4.0 \%$ (Goupia) higher for cellulose compared to wholewood (Fig. 3c, d). The correlation between $\delta^{18} \mathrm{O}$ in wood and in cellulose was also highly significant, but not as tight as for $\delta^{13} \mathrm{C}$ (correlation coefficients of 0.55 and 0.77 for Carapa and Goupia, respectively). Good agreement of $\delta^{18} \mathrm{O}$ in whole-wood and cellulose and correlation of $\delta^{18} \mathrm{O}$ in whole-wood with climate data is often found (Borella et al. 1999; Barbour et al. 2001; Jäggi et al. 2003; but see Ferrio and Voltas 2005; Battipaglia et al. 2008). These comparisons with cellulose gave confidence in the use of whole-wood during the following analytical procedure for interpreting radial variation in isotopic ratios based on existing models that are based on cellulose. Nevertheless, the relatively large unexplained variance for $\delta^{18} \mathrm{O}$ means that radial variation in whole-wood values can be partly the result of variation in chemical composition and/or isotopic variation in other compounds than cellulose.

Radial variation in isotopic composition

The three cores of Carapa had a mean $\delta^{18} \mathrm{O}$ of $25.3 \%$ and a mean $\delta^{13} \mathrm{C}$ of $-27.3 \%$ (Fig. 4). Minima and maxima in $\delta^{18} \mathrm{O}$ could be distinguished with amplitude of $1-4 \%$ at distances of a few millimeters. These were particularly clear in the Carapa tree 47 (Fig. 4). This scale of a few millimeters is similar to the annual radial increment rate (Table 1). A cyclic increase and decrease in $\delta^{18} \mathrm{O}$ could thus be distinguished at a near annual scale in many cases. 
Fig. 3 Comparison of isotope composition of whole-wood and $\alpha$-cellulose. In the panels are shown $\delta^{13} \mathrm{C}(\mathbf{a}, \mathbf{b}), \delta^{18} \mathrm{O}(\mathbf{c}, \mathbf{d})$, Carapa guianensis $(\mathbf{a}, \mathbf{c})$, Goupia glabra $(\mathbf{b}, \mathbf{d})$. A sequence of $200 \mu \mathrm{m}$ thick slices was taken from a part of cores at around $35 \mathrm{~mm}$ depth where no diameter increment was measured
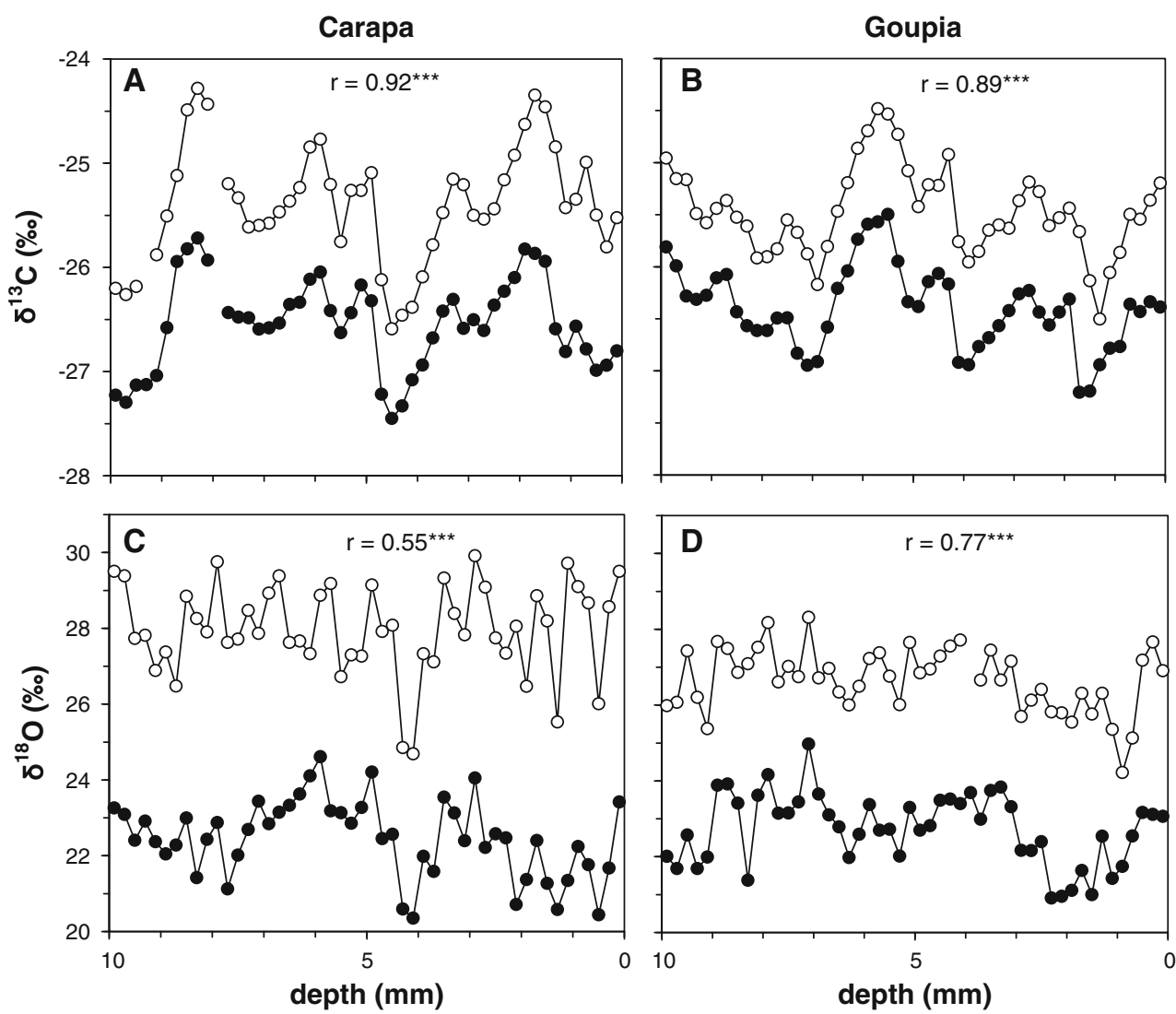

The variation in $\delta^{13} \mathrm{C}$ at this near annual scale was much less $\left(0.5-1.5 \%\right.$ ). Minima in $\delta^{13} \mathrm{C}$ often coincided with the minima in $\delta^{18} \mathrm{O}$ in the case of Carapa tree 47 as also evident from a positive correlation between $\delta^{13} \mathrm{C}$ and $\delta^{18} \mathrm{O}$ (Fig. 4; Table 2). This was less evident in tree 61 that showed a negative correlation (Table 2).

Trends in isotopic composition of the wood could also be distinguished on a longer time scale. In the Carapa tree 61 (Fig. 4 ), $\delta^{18} \mathrm{O}$ decreased abruptly about $2 \%$ at $11 \mathrm{~mm}$ and $\delta^{13} \mathrm{C}$ increased about $1 \%$ at $15 \mathrm{~mm}$. Such longer term trends were absent for $\delta^{18} \mathrm{O}$ in the two cores from the Carapa tree 47. Average values were also similar for both cores. However, $\delta^{13} \mathrm{C}$ reached values of about $-28.5 \%$ in the first few $\mathrm{mm}$ and again at around $15 \mathrm{~mm}$ in the $47-\mathrm{S}$ core. This was not found in the 47-N core where values remained at an average of $-26.5 \%$ throughout. Such variation in $\delta^{13} \mathrm{C}$ around the circumference of a tree stem is frequently found (e.g. Leavitt and Long 1991; Schleser 1999).

The $\delta^{18} \mathrm{O}$ values in the Goupia cores were slightly lower (mean 24.7\%o) compared to the Carapa cores and the $\delta^{13} \mathrm{C}$ values were somewhat higher and were different between the two trees, $-25.2 \%$ and $-26.6 \%$ for the trees 42 and 17 , respectively (Fig. 5). Clear minima and maxima in $\delta^{18} \mathrm{O}$ at a near annual scale could also be distinguished for Goupia, although the amplitude of the cyclic variation was somewhat less compared to Carapa. The average $\delta^{18} \mathrm{O}$ amplitude was around $2 \%$, with an occasionally more pronounced cyclic variation in $\delta^{18} \mathrm{O}$ such as between 4 and $10 \mathrm{~mm}$ in the Goupia tree 42, around $8 \mathrm{~mm}$ in the Goupia $17-\mathrm{N}$ core and between 9 and $18 \mathrm{~mm}$ in the $17-\mathrm{S}$ core (Fig. 5). As in Carapa, the amplitude of variation of $\delta^{13} \mathrm{C}$ in the Goupia cores was also around $1 \%$. No obvious longer-term trend in mean isotopic ratio could be distinguished in the Goupia cores.

The two isotopic ratios were correlated in the three Carapa cores (Table 2) and the $\delta^{13} \mathrm{C}$ minima often coincided with the $\delta^{18} \mathrm{O}$ minima in this species, particularly for tree \#47 where 13 of the 15 annual boundaries were characterized by a low $\delta^{18} \mathrm{O}$ and $\delta^{13} \mathrm{C}$ (see below). This was expected when both isotopic ratios were forced by seasonal changes. However, only one Goupia core showed a significant but not very tight correlation between the two isotopes (Table 2) and the minima for $\delta^{18} \mathrm{O}$ and $\delta^{13} \mathrm{C}$ coincided in only $55 \%$ of the cases.

\section{Intra-annual variation and annual boundaries}

The cyclic variation in $\delta^{18} \mathrm{O}$ over distances in the order of magnitude of the annual radial increment rate (Figs. 4, 5; Table 1) suggests a forcing by seasonally varying environmental conditions. For the most nearby station where 

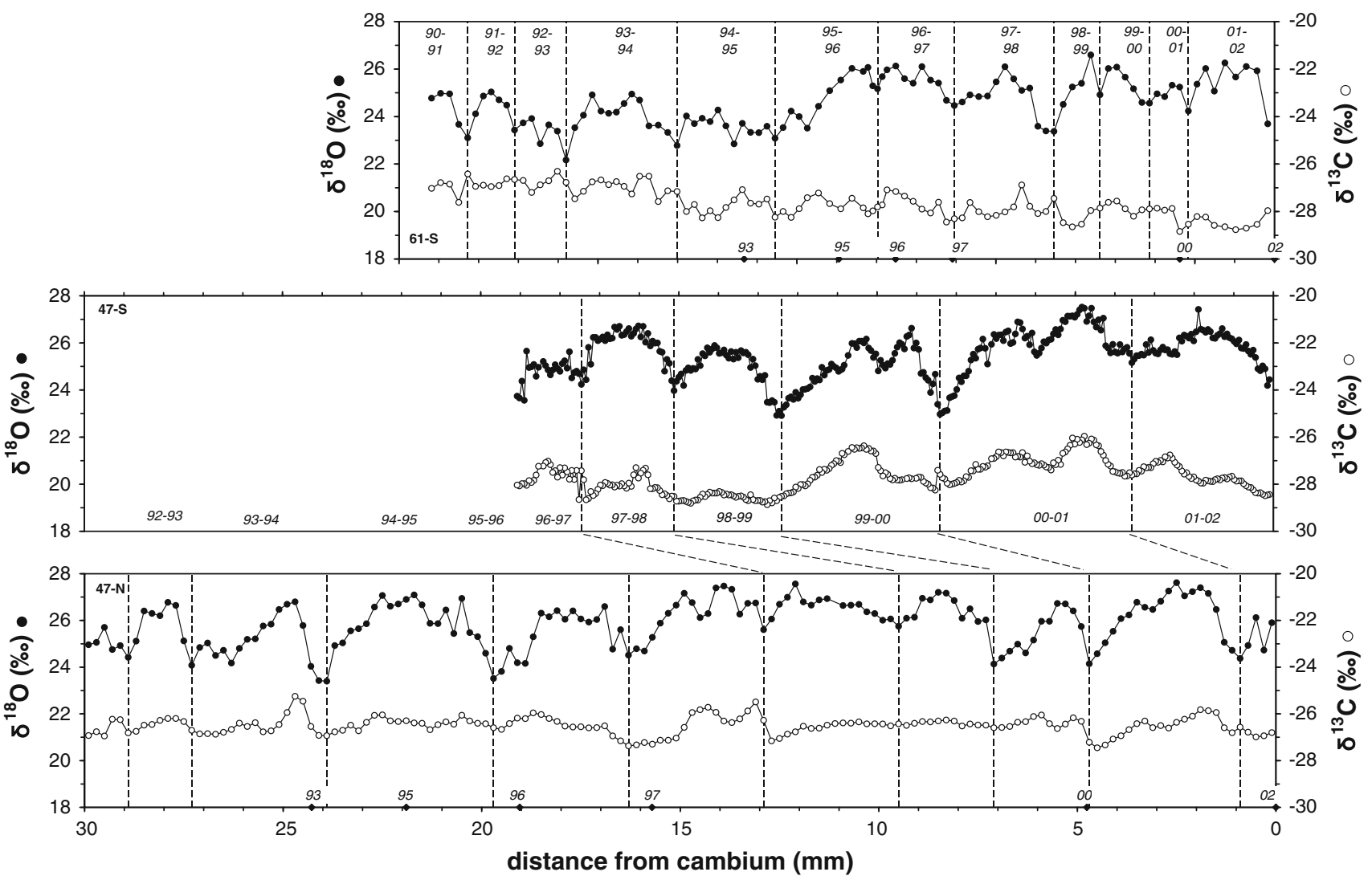

Fig. 4 Radial variation in $\delta^{18} \mathrm{O}$ (filled circle) and $\delta^{13} \mathrm{C}$ (open circle) in the three cores of Carapa guianensis plotted against the distance from the cambium inward. The diamond symbols on the $X$-axis represent the times of diameter measurements: September 1993, February 1995, January 1996, March 1997, October 2000 and May 2002. Annual boundaries at the middle of the main rainy season

Table 2 Correlation between $\delta^{13} \mathrm{C}$ and $\delta^{18} \mathrm{O}$ within individual cores

\begin{tabular}{|c|c|c|c|c|c|c|}
\hline \multirow[t]{2}{*}{ Core } & \multicolumn{3}{|c|}{ Carapa guianensis } & \multicolumn{3}{|c|}{ Goupia glabra } \\
\hline & $61-S$ & $47-S$ & $47-\mathrm{N}$ & $42-S$ & $17-S$ & $17-\mathrm{N}$ \\
\hline$r$ & $-0.37 * * *$ & $0.42 * * *$ & $0.42 * * *$ & $-0.05^{\mathrm{ns}}$ & $0.21 * * *$ & $0.16^{\mathrm{ns}}$ \\
\hline$n$ & 100 & 313 & 149 & 100 & 255 & 149 \\
\hline
\end{tabular}

Pearson correlation coefficients $(r)$ are shown with probability categories (ns $P>0.05$; *** $P<0.001)$ and number of data points $(n)$

precipitation water was measured for $\delta^{18} \mathrm{O}$, Cayenne in French Guiana, a $3 \%$ lower $\delta^{18} \mathrm{O}$ was reported for the middle of the rainy season compared to the dry season (Fig. 2). Similar or even larger seasonal differences are reported for several stations in the humid tropics of west and central Amazonia (WISER database, http://nds121. iaea.org/wiser/). Source water determines largely the isotopic composition of wood (Roden and Ehleringer 1999). The low $\delta^{18} \mathrm{O}$ in precipitation water is thus likely to be a principal driving force for a low in $\delta^{18} \mathrm{O}$ in wood, since evaporative enrichment is relatively less important in the
(May-June) were distinguished primarily on the basis of $\delta^{18} \mathrm{O}$ when they are expected to be lowest. These are shown as vertical dashed lines with the corresponding years in italic. Cores 61-S and 47-N were sampled at a frequency of $200 \mu \mathrm{m}$ and $47-\mathrm{S}$ at $60 \mu \mathrm{m}$. Cores $47-\mathrm{S}$ and 47-N were sampled from the south and north side of the same tree. Corresponding annual boundaries are connected with dashed lines

rainy season. In the dry season, isotopic enrichment in the leaf (Farquhar and Gan 2003) and in the upper soil layers (Jackson et al. 1995; Bonal et al. 2000a) on top of the higher $\delta^{18} \mathrm{O}$ in precipitation water is likely to have further increased $\delta^{18} \mathrm{O}$ in the wood and may thus have enlarged the amplitude of seasonal variation. A complicating factor is that the depth of water uptake of the trees is unknown, and the isotopic composition of soil water may vary with depth as found for a comparable forest in French Guiana (Bonal et al. 2000a). Nevertheless, a valid assumption is that a low $\delta^{18} \mathrm{O}$ in the cores would represent wood formed in the rainy season and high values represent wood formed in the drier seasons. The cores were sampled at the beginning of the rainy season (2 May 2002) and the low $\delta^{18} \mathrm{O}$ of the precipitation water was apparently already reflected in the most recently formed wood directly under the cambium of some cores (Figs. 4 , cores 61-S and 47-S, 5, core 42-S), but in other cores not yet (Figs. 4, core 47-N, 5, core 17-S and $17-\mathrm{N}$ ). The number of data points at the minimum $\mathrm{d} 18 \mathrm{O}$ is small in most cases. This is remarkable when it is assumed that this indicates the wood that is formed in the 

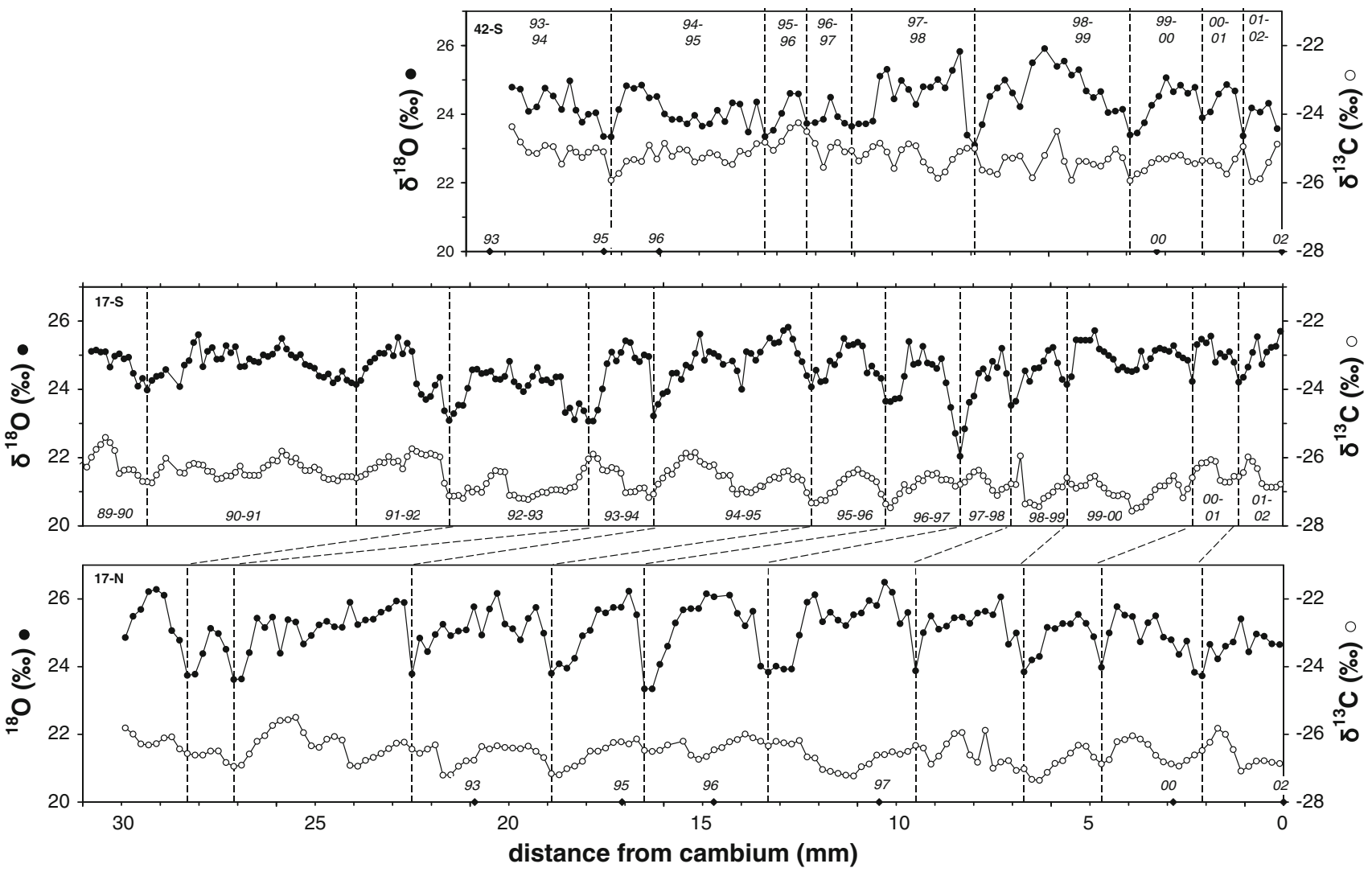

Fig. 5 Radial variation in $\delta^{18} \mathrm{O}$ (filled circle) and $\delta^{13} \mathrm{C}$ (open circle) in the three cores of Goupia glabra plotted against the distance from the cambium inward. The diamond symbols on the $X$-axis represent the times of diameter measurements (for dates see Fig. 4). Annual boundaries at the middle of the main rainy season (May-June) are

rainy season, because it suggests that a small fraction of the wood is formed in this season that is at least 4 months. A possible reason could be that the minimum of $\delta^{18} \mathrm{O}$ in precipitation is of shorter duration that the rainy season as a whole.

The variation in $\delta^{13} \mathrm{C}$ of about $1 \%$ within the annual radial growth of $2 \mathrm{~mm}$ in both species (Figs. 4, 5) was small compared to the intra-annual variation reported from temperate (Leavitt and Long 1991; Helle and Schleser 2004; Roden et al. 2009) and other tropical areas (Poussart et al. 2004; Verheyden et al. 2004b). Part of the intraannual variation in $\delta^{13} \mathrm{C}$ in deciduous temperate trees is caused by utilization of stored reserves for wood formation in spring (Gessler et al. 2009). That is not likely to play an important role in two species that may only lose part of their foliage in the dry season. Increased stomatal limitation of photosynthesis in the dry season because of decreased water availability as measured in comparable forest (Huc et al. 1994; Bonal et al. 2000b; Dünisch and Morais 2002) and/or increased irradiance are other possible candidates for explaining intra-annual variation in $\delta^{13} \mathrm{C}$. An effect of water availability on $\delta^{13} \mathrm{C}$ in wood has been shown as vertical dashed lines with the corresponding years in italic. Cores 42-S and 17-N were sampled at a frequency of $200 \mu \mathrm{m}$ and 17$\mathrm{S}$ at $120 \mu \mathrm{m}$. Cores $17-\mathrm{S}$ and $17-\mathrm{N}$ were sampled from the south and north side of the same tree. Corresponding annual boundaries are connected with dashed lines

shown in the area where trees were sampled along a slope from a sandy ridge to a moist valley (Pons et al. 2005). However, dry season droughts as occurred during the measurement period induced only small increases in $\delta^{13} \mathrm{C}$ in both species. These dry periods are apparently not stressful for the trees where they were sampled.

Based on the above reasoning, annual boundaries were drawn that supposedly represent the middle of the rainy season (May-June). A minimum in $\delta^{18} \mathrm{O}$ was used as the principal criterion, preferably supported by more than one data point. A low $\delta^{13} \mathrm{C}$ was used as a secondary argument. Using those criteria, the core Carapa $61-\mathrm{S}$ showed a reasonably good match with the radial increment rate (Fig. 4). The isotopic patterns in the two cores from opposite sides of the tree Carapa 47 did not seem to match (Fig. 4). However, when different growth rates in different years were assumed for the two sides of the stem, then the patterns showed a better match. The isotopic pattern shows evidence for faster growth of the south compared to the north side of the stem up to $12 \mathrm{~mm}$ depth, but slower growth between 12 and $20 \mathrm{~mm}$. The cores from both sides showed also a reasonable match with the measured radial 
growth. The parenchyma bands visible in the cores of Carapa were fewer then the annual boundaries based on isotopes and also based on the radial increment over the measured period. Hence, anatomical increment zones are not likely to be annual in Carapa as also concluded by Dünisch et al. (2002). Some uncertainty remains with the identification of annual boundaries where the minimum in $\delta^{18} \mathrm{O}$ is not so clear and does not coincide with a minimum in $\delta^{13} \mathrm{C}$. This can be seen in the cores $61-\mathrm{S}$ (at 3.1, 15 and $20.3 \mathrm{~mm}$ ) and $47-\mathrm{N}$ (at $9.5 \mathrm{~mm}$ ) that were both sampled at a lower resolution compared to $47-\mathrm{S}$. We conclude that annual rings can be distinguished in the wood of Carapa guianensis with reasonable certainty on the basis of radial variation in isotopic ratios, particularly when sampled at high resolution.

The core Goupia 42-S showed a clear cyclic isotopic pattern to a depth of $11 \mathrm{~mm}$ depth, but less so beyond that point (Fig. 5). Nevertheless, when applying the criteria, the annual boundaries matched radial growth reasonably well. The two cores from the Goupia 17 tree were also difficult to match. A satisfactory match was only possible when a faster growth rate of the north side than the mean radial increment rate to a depth of $25 \mathrm{~mm}$ was assumed and a slower growth of the south side up to $14 \mathrm{~mm}$ (Fig. 5). Beyond $14 \mathrm{~mm}$ depth in the $\mathrm{S}$ core, there is evidence of accelerated growth, although the isotopic pattern became less clear towards the end. The cross section of the Goupia samples showed some variation in frequency of vessels and axial parenchyma, but this was not associated with the radial growth and/or annual boundaries distinguished based on stable isotopes. In addition, in samples of Goupia glabra some uncertainty remained regarding the demarcation of annual boundaries. Nevertheless, we can also conclude for this species that, although variation in $\delta^{18} \mathrm{O}$ was less, annual rings can be distinguished with reasonable certainty from radial variation in isotopic ratios. In both species, $\delta^{18} \mathrm{O}$ was much more useful for distinguishing annual boundaries compared to $\delta^{13} \mathrm{C}$.

Other studies have also identified annual rings in tropical rainforest trees where they are anatomically non-distinct. Those done with trees from drier tropics and/or tropical climates with a single pronounced dry season often yielded a clear annual pattern in $\delta^{18} \mathrm{O}$ and in some cases also $\delta^{13} \mathrm{C}$ with larger intra-annual variation (Poussart et al. 2004; Poussart and Schrag 2005; Anchukaitis et al. 2008). The tree sampled in the humid La Selva forest in Eastern Costa Rica by Evans and Schrag (2004) showed similar intra-annual variation in $\delta^{18} \mathrm{O}$ as in the present study and annual cycles could also be recognized. Hence, annual rings can be identified by means of radial variations in $\delta^{18} \mathrm{O}$ not only in tropical climates with a pronounced dry season, but also in the more humid tropics. However, independent verification of age, e.g. with radio carbon, would be necessary when applying the technique to longer sequences (Poussart et al. 2004; Poussart and Schrag 2005).

Relationships with climate variability

A negative relationship of amount of precipitation with $\delta^{18} \mathrm{O}$ in wood is expected since correlation with amount also exists with $\delta^{18} \mathrm{O}$ in precipitation water (Bonal et al. 2000a). Likewise, a negative relationship is also supposed to be present for $\delta^{13} \mathrm{C}$ because of the decreasing stomatal limitation with increasing precipitation. These relationships would result in a positive correlation between $\delta^{13} \mathrm{C}$ and $\delta^{18} \mathrm{O}$. This was indeed found for the three Carapa cores, but only for one of the three Goupia cores (Table 2). Poussart and Schrag (2005) and Roden (2008) found similarities of annual $\delta^{18} \mathrm{O}$ cycles between trees growing in the same area when the seasonal variation in the wood was forced by $\delta^{18} \mathrm{O}$ of precipitation water and isotopic enrichment in the dry season. Variations in minima and maxima in $\delta^{18} \mathrm{O}$ was evident in our samples (Figs. 4, 5), but a clear matching between the cores from different trees was not possible.

The correlation of various precipitation parameters with isotopic parameters was analyzed. Precipitation parameters were, annual totals (May-April), the main rainy season (restricted to the generally wettest part, May-July), the part of the year outside the main rainy season (SeptemberMarch) and the main dry season (September-November). Data were derived from the local observations (Fig. 1), which unfortunately have missing data for the 1994-1996 period, and from the climate research unit dataset CRU TS 2.1 (Mitchell and Jones 2005) that contains interpolated precipitation data for the whole measurement period. The CRU data are on average $21 \%$ higher than the measured data, which is similar for the 1965-1973 period of continuous records at the Great Falls meteorological station near the samples site (Jetten 1994). The CRU data are apparently representing an overestimate of the precipitation at the sample site. Isotopic data were averaged per identified year, and the minimum and maximum values in each year, the putative rainy and dry seasons, respectively, were calculated as the average for three data points. The number of data points was increased to cover the same radial interval $(0.6 \mathrm{~mm})$ for the $60 \mu \mathrm{m}$ high-resolution cores (Carapa 47-S and Goupia 17-S).

No significant correlations were found of precipitation parameters with $\delta^{13} \mathrm{C}$, also no non-significant trends were evident (data not shown). Relationships of $\delta^{18} \mathrm{O}$ with precipitation were also not unequivocal. Nevertheless, in some cores, the expected negative trend of annual and rainy season precipitation with $\delta^{18} \mathrm{O}$ was present (Table 3), but that was significant in only one case (Carapa 47-S with annual CRU data). Although the minima in $\delta^{18} \mathrm{O}$ were not 
Table 3 Correlation of precipitation with $\delta^{18} \mathrm{O}$ in the three cores of the two species each

\begin{tabular}{lrlllllll}
\hline & \multicolumn{3}{c}{ Carapa guianensis } & & \multicolumn{3}{c}{ Goupia glabra } \\
\cline { 2 - 3 } & $61-\mathrm{S}$ & $47-\mathrm{S}$ & $47-\mathrm{N}$ & & $42-\mathrm{S}$ & $17-\mathrm{S}$ & $17-\mathrm{N}$ \\
\hline Annual & & & & & & & \\
Recorded & 0.34 & -0.55 & -0.06 & & -0.47 & -0.16 & -0.04 \\
CRU & 0.46 & $-0.94 *$ & -0.28 & & -0.13 & -0.65 & 0.05 \\
Rainy season & & & & & & \\
Recorded & -0.20 & 0.82 & $0.89 * *$ & -0.44 & -0.28 & 0.18 \\
CRU & 0.27 & 0.23 & 0.27 & -0.36 & -0.24 & 0.26 \\
\hline
\end{tabular}

Pearson correlation coefficients $(r)$ with probability categories (* $P<0.05$; ** $P<0.01$ ) are shown for the amount of annual precipitation with annually averaged $\delta^{18} \mathrm{O}$ and for rainy season precipitation (May-July) with the amplitude of the annual $\delta^{18} \mathrm{O}$ cycle. Two sets of precipitation data were used. One dataset was recorded at the sampling site and in the close vicinity as presented in Fig. 1. The other dataset was obtained from the climate research unit (http://www.cru.uea.ac.uk/cru/data/; CRU ST 2.1). The interpolated data from the four nearest grid points were averaged and used for the analysis

related to the amount of rainy season precipitation, the amplitude of intra-annual variation in $\delta^{18} \mathrm{O}$ was positively related to the locally measured rainy season precipitation in one case (Carapa 47-N with recorded data) (Table 3). The ENSO event of 1997/1998 with reduced precipitation in the main rainy season of 1997 and in the following seasons (Fig. 1) was also not reflected by a higher $\delta^{18} \mathrm{O}$ and/or $\delta^{13} \mathrm{C}$. Some other studies of isotopic variation in tropical trees lacking visually distinct annual rings report better relationships with precipitation, such as Poussart and Schrag (2005) for Northern Thailand, Anchukaitis et al. (2008) for montane forest and Evans (2007) for a lowland forest in Costa Rica. The climate in these locations is characterized by a single dry season, which, in the case of Thailand and the montane forest in Costa Rica, was accompanied by larger annual amplitude of variation in $\delta^{18} \mathrm{O}$ compared to our study. A reason for the lack of clear relationships between precipitation and $\delta^{18} \mathrm{O}$ could be the presence of a second dry and wet season in our area, which may complicate the pattern of the intra-annual isotopic variation. Further reasons could be a small effect of climatic variation on $\delta^{18} \mathrm{O}$ of precipitation water, uptake of water from greater depths where the isotopic signal is different from precipitation water, the short chronologies resulting in few data points and uncertainties with the demarcation of annual boundaries.

\section{Conclusions}

The small radial variation in $\delta^{13} \mathrm{C}$ makes this parameter unsuitable for the identification of annual rings in the homogeneous wood of the two species that were investigated, and also as proxy for temporal variability in water availability. However, annual rings could be identified with reasonable certainty mainly based on radial variation in $\delta^{18} \mathrm{O}$, but suitability of $\delta^{18} \mathrm{O}$ as precipitation proxy needs further investigation. Longer tree chronologies including stronger climatic anomalies may result in a more distinct climate signal. The rings identified with stable isotopes, when supported by alternative dating methods, can be used to retrospectively analyze growth. The large numbers of samples required for a dendrological approach may still be prohibitive, but the method may become more practically useful when prototypes of high precision automatic analysis methods like UV-Laser Ablation-combustion-Isotope Ratio Mass-Spectrometry (LA-IRMS, Schulze et al. 2004) or Laser-Micro-Dissection Pyrolysis Mass-Spectrometry (LMD-P-IRMS) are developed into marketable commodity.

Acknowledgments The study was based on the organizational structure of the Guyana program of Tropenbos International. Dr. Eric Arets sampled and measured the trees, Dr. Peter van der Hout made tree growth data from earlier measurements available and Dr. Rachel Thomas then at the Guyana Forestry Commission provided logistical support. Yvonne de Jong-van Berkel, Carmen Bürger, Olga Dietz and Steffi Andres are thanked for their precise and persistent laboratory work. This work was partly funded by the EU-projects ISONET (EVK2-CT-2002-00149)) and MILLENNIUM (017008-2).

Open Access This article is distributed under the terms of the Creative Commons Attribution Noncommercial License which permits any noncommercial use, distribution, and reproduction in any medium, provided the original author(s) and source are credited.

\section{References}

Anchukaitis KJ, Evans MN, Wheelwright NT, Schrag DP (2008) Stable isotope chronology and climate signal calibration in neotropical montane cloud forest trees. J Geophys Res 113:G03030

Araguas-Araguas L, Froehlich K, Rozanski K (2000) Deuterium and oxygen-18 isotope composition of precipitation and atmospheric moisture. Hydrol Process 14:1341-1355

Barbour MM (2007) Stable oxygen isotope composition of plant tissue: a review. Funct Plant Biology 34:83-94

Barbour MM, Andrews TJ, Farquhar GD (2001) Correlations between oxygen isotope ratios of wood constituents of Quercus and Pinus samples from around the world. Aust J Plant Physiol 28:335-348

Battipaglia G, Jäggi M, Saurer M, Siegwolf RTW, Cotrufo MF (2008) Climatic sensitivity of $\delta^{18} \mathrm{O}$ in the wood and cellulose of tree rings: Results from a mixed stand of Acer pseudoplatanus L. and Fagus sylvatica L. Palaeogeogr Palaeocl 261:193-202

Bonal D, Atger C, Barigah TS, Ferhi A, Guehl JM, Ferry B (2000a) Water acquisition patterns of two wet tropical canopy tree species of French Guiana as inferred from $\mathrm{H}_{2}^{18} \mathrm{O}$ extraction profiles. Ann For Sci 57:717-724

Bonal D, Barigah TS, Granier A, Guehl JM (2000b) Late-stage canopy tree species with extremely low $\delta^{13} \mathrm{C}$ and high stomatal sensitivity to seasonal soil drought in the tropical rain forest of French Guiana. Plant Cell Environ 23:445-459 
Borella S, Leuenberger M, Saurer M (1999) Analysis of $\delta^{18} \mathrm{O}$ in tree rings: Wood-cellulose comparison and method dependent sensitivity. J Geophys Res 104:19267-19273

Brienen RJW, Zuidema PA (2005) Relating tree growth to rainfall in Bolivian rain forests: a test for six species using tree ring analysis. Oecologia 146:1-12

Brienen RJW, Zuidema PA (2006) Lifetime growth patterns and ages of Bolivian rain forest trees obtained by tree ring analysis. J Ecol 94:481-493

Brienen RJW, Wanek W, Hietz P (2010) Stable isotopes in tree rings indicate improved water use efficiency and drought responses of a tropical dry forest tree species. Trees. doi:10.1007//s00468010-0474-1

Cullen LE, Adams MA, Anderson MJ, Grierson PF (2008) Analyses of $\delta^{13} \mathrm{C}$ and $\delta^{18} \mathrm{O}$ in tree rings of Callitris columellaris provide evidence of a change in stomatal control of photosynthesis in response to regional changes in climate. Tree Physiol 28:1525-1533

Dünisch O, Morais RR (2002) Regulation of xylem sap flow in an evergreen, a semi-deciduous, and a deciduous Meliaceae species from the Amazon. Trees-Struct Funct 16:404-416

Dünisch O, Bauch J, Gasparotto L (2002) Formation of increment zones and intra-annual growth dynamics in the xylem of Swietenia macrophylla, Carapa guianensis, and Cedrela odorata (Meliaceae). IAWA J 23:101-119

Eglin T, Maunoury-Danger F, Fresneau C, Lelarge C, Pollet B, Lapierre C, Francois C, Damesin C (2008) Biochemical composition is not the main factor influencing variability in carbon isotope composition of tree rings. Tree Physiol 28:1619-1628

Evans MN (2007) Toward forward modeling for paleoclimatic proxy signal calibration: A case study with oxygen isotopic composition of tropical woods. Geochem Geophys Geosyst 8:Q07008

Evans MN, Schrag DP (2004) A stable isotope-based approach to tropical dendroclimatology. Geochim Cosmochim 68:3295-3305

Farquhar GD, Gan KS (2003) On the progressive enrichment of the oxygen isotopic composition of water along a leaf. Plant Cell Environ 26:801-819

Farquhar GD, O'Leary MH, Berry JA (1982) On the relationship between carbon isotope discrimination and the intercellular carbon dioxide concentration in leaves. Aust J Plant Physiol 9:121-137

Farquhar GD, Ehleringer JR, Hubick KT (1989) Carbon isotope discrimination and photosynthesis. Annu Rev Plant Physiol Plant Mol Biol 40:503-537

Ferrio JP, Voltas J (2005) Carbon and oxygen isotope ratios in wood constituents of Pinus halepensis as indicators of precipitation, temperature and vapour pressure deficit. Tellus Ser B 57:164-173

Francey RJ, Farquhar GD (1982) An explanation of ${ }^{13} \mathrm{C} /{ }^{12} \mathrm{C}$ variations in tree rings. Nature 297:28-31

Gessler A, Brandes E, Buchmann N, Helle G, Rennenberg H, Barnard RL (2009) Tracing carbon and oxygen isotope signals from newly assimilated sugars in the leaves to the tree-ring archive. Plant Cell Environ 32:780-795

Green JW (1963) Wood cellulose. In: Whistler RL (ed) Methods in carbohydrate chemistry III. Academic Press, New York, pp 9-22

Harlow BA, Marshall JD, Robinson AP (2006) A multi-species comparison of $\delta^{13} \mathrm{C}$ from whole wood, extractive-free wood and holocellulose. Tree Physiol 26:767-774

Heinrich I, Weidner K, Helle G, Vos H, Banks JCG (2008) Hydroclimatic variation in Far North Queensland since 1860 inferred from tree rings. Palaeogeogr Palaeocl 270:116-127

Helle G, Schleser GH (2004) Beyond $\mathrm{CO}_{2}$-fixation by Rubisco-an interpretation of ${ }^{13} \mathrm{C} /{ }^{12} \mathrm{C}$ variations in tree rings from novel intra-seasonal studies on broad-leaf trees. Plant Cell Environ $27: 367-380$
Hietz P, Wanek W, Dunisch O (2005) Long-term trends in cellulose $\delta^{13} \mathrm{C}$ and water-use efficiency of tropical Cedrela and Swietenia from Brazil. Tree Physiol 25:745-752

Huc R, Ferhi A, Guehl JM (1994) Pioneer and late stage tropical rainforest tree species (French Guiana) growing under common conditions differ in leaf gas exchange regulation, carbon isotope discrimination and water potential. Oecologia 99:297-305

Jackson PC, Cavelier J, Goldstein G, Meinzer FC, Holbrook NM (1995) Partitioning of water-resources among plants of a lowland tropical forest. Oecologia 101:197-203

Jacoby GC (1989) Overview of tree-ring analysis in tropical regions. IAWA Bull 10:99-108

Jäggi M, Saurer M, Fuhrer J, Siegwolf R (2003) Seasonality of $\delta^{18} \mathrm{O}$ in needles and wood of Picea abies. New Phytol 158:51-59

Jetten VG (1994) Modelling the effects of logging on the water balance of a tropical rain forest. A study in Guyana, Tropenbos Series 6. Tropenbos International, Wageningen

Kagawa A, Sugimoto A, Maximov TC (2006) Seasonal course of translocation, storage and remobilization of ${ }^{13} \mathrm{C}$ pulse-labeled photoassimilate in naturally growing Larix gmelinii saplings. New Phytol 171:793-804

Leavitt SW, Long A (1991) Seasonal stable isotope variability in tree rings-possible paleoenvironmental signals. Chem Geol 87:59-70

Loader NJ, Robertson I, Barker AC, Switsur VR, Waterhouse JS (1997) A modified method for the batch processing of small whole wood samples to $\alpha$-cellulose. Chem Geol 136:313-317

Loader NJ, Robertson I, McCarroll D (2003) Comparison of stable carbon isotope ratios in the wholewood, cellulose and lignin of oak tree-rings. Palaeogeogr Palaeocl 196:395-407

McCarroll D, Loader NJ (2004) Stable isotopes in tree rings. Q Sci Rev 23:771-801

Miller RB, Détiene P (2001) Major timber trees of Guyana Wood anatomy Tropenbos Series 20. Tropenbos International, Wageningen

Mitchell TD, Jones PD (2005) An improved method of constructing a database of monthly climate observations and associated highresolution grids. Int J Climatol 25:693-712

Pons TL, Alexander EE, Houter NC, Rose SA, Rijkers T (2005) Ecophysiological patterns in Guianan forest plants. In: Hammond DS (ed) Tropical forests of the Guiana Shield. CABI Publishing, Wallingford, pp 195-231

Poussart PF, Schrag DP (2005) Seasonally resolved stable isotope chronologies from northern Thailand deciduous trees. Earth Planet Sci Lett 235:752-765

Poussart PF, Evans MN, Schrag DP (2004) Resolving seasonality in tropical trees: multi-decade, high-resolution oxygen and carbon isotope records from Indonesia and Thailand. Earth Planet Sci Lett 218:301-316

Roden $\mathrm{J}$ (2008) Cross-dating of tree ring $\delta^{18} \mathrm{O}$ and $\delta^{13} \mathrm{C}$ time series. Chem Geol 252:72-79

Roden JS, Ehleringer JR (1999) Hydrogen and oxygen isotope ratios of tree ring cellulose for riparian trees grown long term under hydroponically controlled environments. Oecologia 121:467-477

Roden JS, Lin GG, Ehleringer JR (2000) A mechanistic model for interpretation of hydrogen and oxygen isotope ratios in tree ring cellulose. Geochim Cosmochim 64:21-35

Roden JS, Johnstone JA, Dawson TE (2009) Intra-annual variation in the stable oxygen and carbon isotope ratios of cellulose in tree rings of coast redwood (Sequoia sempervirens). Holocene 19:189-197

Schleser GH (1999) ${ }^{13} \mathrm{C} /{ }^{12} \mathrm{C}$ in growth rings and leaves: carbon distribution in trees. In: Jones TP, Rowe NP (eds) Fossil plants and spores: modern techniques. The Geological Society, London, pp 306-309 
Schöngart J, Piedade MTF, Ludwigshausen S, Horna V, Worbes M (2002) Phenology and stem-growth periodicity of tree species in Amazonian floodplain forests. J Trop Ecol 18:581-597

Schulze B, Wirth C, Linke P, Brand WA, Kuhlmann I, Horna V, Schulze ED (2004) Laser ablation-combustion-GC-IRMS-a new method for online analysis of intra-annual variation of $\delta^{13} \mathrm{C}$ in tree rings. Tree Physiol 24:1193-1201

Sternberg LDLO (2009) Oxygen stable isotope ratios of tree-ring cellulose: the next phase of understanding. New Phytol 181: $553-562$

Ter Steege H, Persaud C (1991) The phenology of Guyanese timber species: a compilation of a century of observations. Vegetation 95:177-198

van DamO (2001) Forest filled with gaps. Effects of gap size on water and nutrient cycling in tropical rain forest. A study in Guyana. Tropenbos-Guyana Series 10, Georgetown, Guyana van der Hout P (1999) Reduced impact logging in the tropical rain forest of Guyana, Tropenbos-Guyana Series 6, Georgetown, Guyana

Verheyden A, Helle G, Schleser GH, Dehairs F, Beeckman H, Koedam N (2004a) Annual cyclicity in high-resolution stable carbon and oxygen isotope ratios in the wood of the mangrove tree Rhizophora mucronata. Plant Cell Environ 27:1525-1536

Verheyden A, Kairo JG, Beeckman H, Koedam N (2004b) Growth rings, growth ring formation and age determination in the mangrove Rhizophora mucronata. Ann Bot 94:59-66

Verheyden A, Roggeman M, Bouillon S, Elskens M, Beeckman H, Koedam N (2005) Comparison between $\delta^{13} \mathrm{C}$ of alpha-cellulose and bulk wood in the mangrove tree Rhizophora mucronata: implications for dendrochemistry. Chem Geol 219:275-282

Worbes M (2002) One hundred years of tree-ring research in the tropics-a brief history and outlook to future challenges. Dendrochronologia 20:217-231 